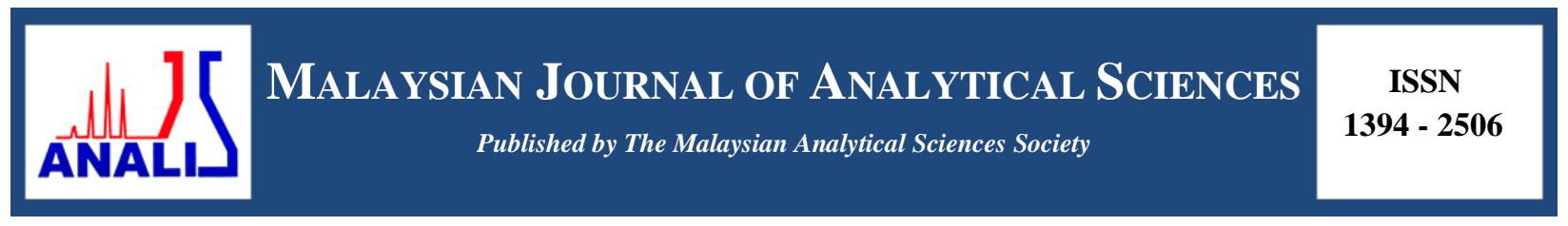

\title{
MAGNETITE GRAPHENE FOR ELECTROCHEMICAL DETERMINATION OF URIC ACID
}

\author{
(Magnetit Grafin untuk Penentuan Elektrokimia Asid Urik) \\ Yee Kin Weng, Azleen Rashidah Mohd Rosli, Farhanini Yusoff* \\ School of Marine and Environmental Sciences, \\ Universiti Malaysia Terengganu, 21030 Kuala Nerus, Terengganu, Malaysia \\ *Corresponding author: farhanini@umt.edu.my
}

Received: 17 February 2019; Accepted: 22 May 2019

\begin{abstract}
In this work, the magnetite-reduced graphene oxide $\left(\mathrm{Fe}_{3} \mathrm{O}_{4} / \mathrm{rGO}\right)$ was fabricated for a selective voltammetric detection of uric acid. The magnetite-reduced graphene oxide is biocompatible sensing material that was synthesized through one-step reaction mechanism. The attachment of spherical like $\mathrm{Fe}_{3} \mathrm{O}_{4}$ particle on the rGO sheet was characterized by Fourier Transform Infrared (FTIR), Ultraviolet-Visible Spectroscopy (UV-Vis) and Scanning Electron Microscopy (SEM). The electrochemical performance of the $\mathrm{Fe}_{3} \mathrm{O}_{4} / \mathrm{rGO} / \mathrm{GCE}$ electrode were studied by Cyclic Voltammetry (CV) and Differential Pulse Voltammetry (DPV). The superparamagtism property of the $\mathrm{Fe}_{3} \mathrm{O}_{4}$ anchoring on the rGO sheet provides a conduction pathway for the analyte diffusion meanwhile promote the electron transfer kinetic between the electroactive species and electrode surface. The enhanced current response signal produced from the reduction-oxidation process by the electroactive species were optimized further in parameters of scan rate, concentration of uric acid and $\mathrm{pH}$ value of the supporting electrolyte. The observed DPV response displays a linearity relationship on uric acid concentration ranging from $4 \mu \mathrm{M}$ to $100 \mu \mathrm{M}$ with correlation coefficient 0.989 and a sensitivity of $0.08478 \mu \mathrm{A} / \mu \mathrm{M}$. The detection limit and limit of quantitation were found to be $3.04 \mu \mathrm{M}$ and $10.14 \mu \mathrm{M}$ respectively.
\end{abstract}

Keywords: magnetite, reduced graphene oxide, uric acid, electrochemical sensor

\begin{abstract}
Abstrak
Dalam hasil kerja ini, magnetit-grafin oksida terturun $\left(\mathrm{Fe}_{3} \mathrm{O}_{4} / \mathrm{rGO}\right)$ telah difabrikasikan untuk tujuan pengesanan voltametrik terpilih bagi asid urik. Magnetit-grafin oksida terturun merupakan bahan sensor bioserasi yang telah disintesis melalui mekanisma tindak balas satu langkah. Pelekatan zarah sfera $\mathrm{Fe}_{3} \mathrm{O}_{4}$ pada lembaran rGO telah dicirikan menggunakan Inframerah Transformasi Fourier (FTIR), Spektroskopi Sinar Ultra Lembayung Terlihat (UV-Vis), dan Mikroskop Imbasan Elektron (SEM). Prestasi elektrokimia elektrod $\mathrm{Fe}_{3} \mathrm{O}_{4} / \mathrm{rGO} / \mathrm{GCE}$ telah dikaji menggunakan kaedah Voltametri Berkitar (CV) dan Voltammetri Pembezaan Denyutan (DPV). Ciri-ciri superparamagnetisma $\mathrm{Fe}_{3} \mathrm{O}_{4}$ yang terlekat di atas lembaran rGO menyediakan laluan konduktif untuk penyerapan analit dan juga meningkatkan kinetik pemindahan elektron di antara spesies elektroaktif dan permukaan elektrod. Peningkatan isyarat tindakbalas arus yang dihasilkan dari proses pengoksidaan dan pengurangan oleh spesies elektroaktif telah dioptimumkan lebih lanjut didalam pengoptimuman kadar imbasan, kepekatan asid urik dan nilai $\mathrm{pH}$ elektrolit sokongan. DPV yang telah diperhatikan menunjukkan hubungan linear di antara kepekatan asid urik antara $4 \mu \mathrm{M}$ sehingga $100 \mu \mathrm{M}$ berserta pekali kolerasi 0.989 dan sensitivity $0.08478 \mu \mathrm{A} / \mu \mathrm{M}$. Had pengesanan dan had kuantifikasi masingmasing adalah $3.04 \mu \mathrm{M}$ dan $10.14 \mu \mathrm{M}$.
\end{abstract}

Kata kunci: magnetit, grafin oksida terturun, asid urik, sensor elektrokimia 


\section{Introduction}

Uric acid (UA) is a biomolecule compound that plays significant role in regulate the homeostasis and metabolism system of the human body. The relative concentration of the UA varies dependently on tissue sites, which may accumulate temporarily or localized for extended period [1]. The UA that is sparingly water-soluble biochemical compound can be determined in the blood serum and excretion waste of the mammalian in the forms of urine. The clinical screening assessment for the uric acid serve as the fundamental tool in understanding various clinical conflicts that link to the uric acid level in human body. The abnormal amount of uric acid may potentially associated with diseases in term of chronic and acute that hold the risk of fatality [2]. The type of diseases that show close relationship to the abnormal amount of uric acid in body fluid including gout, hyperuricemia, rheumatoid and arthritis. Abnormal elevation in the level of uric acid in the body fluid will probably results several recognized clinical problem, which uric acid probably serve as the etiological agent. At high concentration, the uric acid can converted into oxidative radical and its derivatives, which has high cellular permeability and ability to interrupt during the DNA transcription and translation [3].

Quantitative and qualitative determination of the uric acid are significantly useful to provide related information especially in field of pharmaceutical, nursery, pathology, and medical field. There are varieties of techniques have been proposed with promising sensitivity and consistency in term of detection limit and the amount of uric acid quantified [4, 5]. Recently, electrochemical sensing has been highlighting as sophisticate alternative in identification of disease diagnosis molecules including UA [6]. Meanwhile, due to unique electronic properties and stiffness of the nano-sized graphene carbon allotrope, it has been widely adopted in material development and research activities was intensified on exploitation of graphene in photocatalysis, environmental remediation, and energy storage [1,7]. Graphene is a newly carbon material with nanoscale-dispersed phase at two dimensions other than zero-dimensional fullerene, one-dimensional carbon nanotube, and three-dimensional graphite [8]. The distinctive properties of graphene which are electrochemical beneficial have drawn noticeable attentions among the researchers to uncover its unique structure and properties. The graphene has $2 \mathrm{D}$ honeycomb lattice structure favored by the $\mathrm{sp}^{2}$ hybridization of each carbon atom in the domain. The covalent reinforcement of the domain rendering graphene has strong mechanical strength and making it an ideal material for sustaining the engineering application as well as industrial manufacturing process.

Aside from its excellent physically strength, it has been found that graphene poses large surface-to-volume ratio, high thermal conductivity $\left(3000 \mathrm{~W} \mathrm{~m}^{-1} \mathrm{~K}^{-1}\right)$, and extremely high electron mobility at room temperature $\left(2.0 \times 10^{5}\right.$ $\mathrm{cm}^{2} \mathrm{~V}^{-1} \mathrm{~s}^{-1}$ ) [8]. Such intriguing special of the graphene highly promoted as new potential electrode material for the application in electrochemically determination analyte of interest. A water-dispersible nanocomposite consisting of both magnetite and reduced graphene oxide was designed to address the issue associated with removal of arsenic in typical water treatment process [9]. By coupling both beneficial factors from the graphene and magnetite, the electronic and mechanical performance of the resulting compound may be enhanced. The combinations of excellent electrocatalytic activity of magnetite and good electronic properties of graphene serve as a promising hybrid material on measuring the UA content in biological sample. The UA monitoring examination is clinical diagnostic important as excessive amount of uric acid accumulated may potentially associated with disease of either chronic or acute as well as fatality.

The development of graphene-based hybrid material has been explore through its intended application in electronic industry, microprocessor chipset, and battery manufacture [10]. In order to resolve the difficulties coped in determination of uric acid in real sample, the fabrication of magnetite $\left(\mathrm{Fe}_{3} \mathrm{O}_{4}\right)$ supported on the reduced graphene oxide (rGO) nanocomposite coated on glassy carbon electrode (GCE) is proposed in this paper. The $\mathrm{Fe}_{3} \mathrm{O}_{4} / \mathrm{rGO} / \mathrm{GCE}$ has demonstrated better biocompatibility as compare to bare glassy carbon electrode. Its noticeable electron transfer kinetic enhances the overall performance of the electrochemical instrumental about the desirable sensitivity and selectivity of electrode react with.

\section{Reagent and apparatus}

\section{Materials and Methods}

The concentrated sulfuric acid $\left(\mathrm{H}_{2} \mathrm{SO}_{4}, 98 \%\right)$, hydrochloric acid $(\mathrm{HCl})$, ammonia $\left(\mathrm{NH}_{3}\right)$, potassium permanganate $\left(\mathrm{KMnO}_{4}\right)$, hydrogen peroxide $\left(\mathrm{H}_{2} \mathrm{O}_{2}, 30 \%\right)$ sodium nitrate and uric acid were purchased from the Merck, Germany. 
The natural graphite powder, hydrazine hydrate, iron(II) chloride tetrahydrate $\left(\mathrm{FeCl}_{2} \cdot 4 \mathrm{H}_{2} \mathrm{O}\right)$, and iron(III) chloride hexahydrate $\left(\mathrm{FeCl}_{3} \cdot 6 \mathrm{H}_{2} \mathrm{O}\right)$ were obtained from Merck, Germany. The electrocatalytic performance of the magnetic nanocomposite decorated glassy electrode will be electrochemically analyzed by using 3 -electrode system consists of counter electrode made of a platinum wire, silver/silver chloride electrode (Methrom AUTOLAB, Netherlands), with $3 \mathrm{M}$ of $\mathrm{KCl}$ ) as reference electrode, and magnetite-reduced graphene oxide modified glassy electrode (BASi MF-2012 3.0mm diameter) as the working electrode, with the use of Potentiostat/Galvanostat module PGSTAT (Metrohm AUTOLAB, Nertherlands).

\section{Synthesis of rGO}

Firstly, GO was prepared by modified Hummer's method as reported by Yusoff et al. [11]. The graphene oxide solid sample obtained from the modified Hummers' method was grounded with mortar and pester. The $0.5 \mathrm{~g}$ of fine powder GO first dispersed in deionized water and sonicate for 30 minutes at $60{ }^{\circ} \mathrm{C}$. Later, $5 \mathrm{~g}$ of ascorbic acid added into the homogenized GO solution and stirred with magnetic bar for 30 minutes at $60{ }^{\circ} \mathrm{C}$. The mixture underwent a color changes from yellowish brown to black precipitate, indicative of reduction of GO. The reduction product was treated with centrifugation and remove the supernatant. The black paste of rGO was added with excess $30 \%$ hydrogen peroxide to eliminate the unreacted AA by sonicating for 30 minutes at $60{ }^{\circ} \mathrm{C}$. After sonication, the resulted black solid was obtained by centrifugation and wash with ethanol, deionized water 3 times respectively, and dried in the oven at $100{ }^{\circ} \mathrm{C}$.

\section{Co-precipitation of magnetite}

The ferric $(10.4 \mathrm{~g})$ and ferrous chloride $(4.0 \mathrm{~g})$ can be prepared in a 2:1 mole ratio in $200 \mathrm{~mL}$ of degassed deionized water. The solution containing both ferric and ferrous species was heated up to $50{ }^{\circ} \mathrm{C}$ for 10 minutes. After the heating process completed, $2 \mathrm{~mL}$ of $25 \%$ ammonium hydroxide was added dropwise into the mixture solution under constant stirring rate at $50{ }^{\circ} \mathrm{C}$. The $\mathrm{pH}$ of the mixture was adjusted using the relatively small amount of sodium hydroxide solution to maintain the solution within the $\mathrm{pH}$ range of 9-10. The solution stirred continuously at the same condition for one hour. The black solid magnetite was separated from the solution using a strong magnet, washed with 1:1 composition mixture of ethanol and deionized water. The solid mass was dried in the oven at $70{ }^{\circ} \mathrm{C}$ for 6 hours.

\section{Preparation of magnetic nanocomposite $\left(\mathrm{Fe}_{3} \mathrm{O}_{4} / \mathrm{rGO}\right)$ through co-precipitation}

The obtained graphite oxide powder $(0.5 \mathrm{~g})$ was homogenized in $300 \mathrm{~mL}$ deionized water through ultra-sonication for 35 minutes. The solutions of ferrous chloride $(0.1584 \mathrm{~g} / 25 \mathrm{~mL})$ and ferric chloride $(0.4055 \mathrm{~g} / 25 \mathrm{~mL})$ will be prepared according to 1:2 molar ratio, which is the elemental stoichiometric need for the exact composition of the magnetite required. The resulting monodispersed solution was added with the as prepared iron (II/III) solutions slowly at room temperature and stirred at low speed power. Next, alkalization of the mixture solution by adding $30 \%$ ammonia solution. The $\mathrm{pH}$ of the mixture was adjusted to a magnitude of 10-11. Later on, the stirring mixture was gradually heated up to $90{ }^{\circ} \mathrm{C}$ and meanwhile promoting a reducing atmosphere by introduction of suitable amount of hydrazine hydrate $(10 \mathrm{~mL})$. The solution heated up for 4 hours at constant stirring condition. The resulting black solution cooled under room atmosphere and filtered with mixture of ethanol and water (1:1). The black powder obtained after drying in the oven at $70{ }^{\circ} \mathrm{C}$ for 2 hours.

\section{Fabrication of the magnetite-graphene composite film}

Prior to the surface modification of the bare glassy carbon electrode ( $3 \mathrm{~mm}$ in diameter), the surface was polished with fine alumina slurry $(0.05 \mu \mathrm{m})$ and rinse thoroughly with deionized water. The GCE will then ultra-sonicate in the acetone and deionized water successively and dry under ambient condition. The $\mathrm{Fe}_{3} \mathrm{O}_{4} / \mathrm{rGO}(1.0 \mathrm{mg})$ was added into $1 \mathrm{~mL}$ of deionized water and produced a homogeneous suspension after completion of one-hour sonication. Finally, $5 \mu \mathrm{L}$ of the $\mathrm{Fe}_{3} \mathrm{O}_{4} / \mathrm{rGO}$ homogenized solution was drop-casted on the pretreated GCE and allowed to dry in a vacuum desiccator for 2 hours.

\section{Electrochemical Measurement}

The $\mathrm{Fe}_{3} \mathrm{O}_{4} / \mathrm{rGO} / \mathrm{GCE}$-modified electrode was used to determine uric acid by electrochemical means. The potential applied varies from -0.2 to 0.8 in order to study the redox behavior of the uric acid under cyclic voltammetry. The unmodified glassy carbon electrode was used to replace the $\mathrm{Fe}_{3} \mathrm{O}_{4} / \mathrm{rGO} / \mathrm{GCE}$-modified electrode in comparison of 
their thermal stability, electron kinetic transfer, electrode performance and efficiency. Other than this, the stability of the electrode designed will investigate at different external condition in the experiment. Parameters such as pH, concentrations and scan rate were used to study the optimum performance of the overall electrochemical system built.

\section{Physical characterization of $\mathrm{Fe}_{3} \mathrm{O}_{4} / \mathrm{rGO}$}

\section{Results and Discussion}

The distinction in the functionalities and moieties of each constituents can be determined using the substrate nature and characteristic peaks demonstrated in the IR spectrum. The pure graphite in Figure 1(a) displays a smooth line passes through the region of 4000 to $1500 \mathrm{~cm}^{-1}$ with no single peak appear. The layer intercalation and surface modification of graphite using the modified Hummers method was indicated successfully by the changes in the shape of the spectrum obtained for GO. The FTIR spectrum of GO shown a broad peak at the region around 2950 $3699 \mathrm{~cm}^{-1}$, which designated to the stretching vibration of $\mathrm{OH}$ groups of water molecules adsorbed on graphene oxide. The oxygen functionalities of the graphene oxide described by the peak value of $1730 \mathrm{~cm}^{-1}, 1400 \mathrm{~cm}^{-1}, 1210$ $\mathrm{cm}^{-1}$, and $1020 \mathrm{~cm}^{-1}$ corresponding to the carbonyl $\mathrm{C}=\mathrm{O}$, carboxyl COO-, epoxy $\mathrm{C}-\mathrm{O}$, and alkoxy $\mathrm{C}-\mathrm{OH}$ stretching vibration $[12,13]$. The absorption band value of $1612 \mathrm{~cm}^{-1}$ being assigned to the aromatic $\mathrm{C}=\mathrm{C}$ stretching vibration of the carbon domain. Upon successful chemical reduction of GO with AA, the characteristic absorption peaks responsible for the oxygen moieties present in the GO no longer observed in the rGO spectrum [14-16]. A significant peak at $580 \mathrm{~cm}^{-1}$ was determined in the spectra of synthesized $\mathrm{Fe}_{3} \mathrm{O}_{4}$ nanocomposite, where it defines the stretching vibrational mode of Fe-O intrinsically at the tetrahedral void [17]. The stretching vibrations of $-\mathrm{OH}$ at low-frequency region of $3400 \mathrm{~cm}^{-1}$ and the band $1612 \mathrm{~cm}^{-1}$ was ascribed to the bending mode of the water molecules absorbed on magnetite surfaces [18]. In the view of spectrum obtained for $\mathrm{Fe}_{3} \mathrm{O}_{4} / \mathrm{rGO}$, the absorption bands being assigned to oxygenated group was greatly reduced in intensity and the transmittance band around 584 $\mathrm{cm}^{-1}$ is attributed to the Fe-O bonding vibration, indicated the existence of magnetite [19]. There are additional symmetric and antisymmetric stretching mode of carboxylic group, $\mathrm{COO}$ - with corresponding absorption peak value at $1585 \mathrm{~cm}^{-1}$ and $1414 \mathrm{~cm}^{-1}$.

The optical properties of each constituent materials was measured and the progressive changes on the optical behavior were studied based on exposure upon the ultraviolet-visible light wavelength region. In Figure 1(b), the pure graphite exhibits no significant absorption peak in the range of $200 \mathrm{~nm}$ to $800 \mathrm{~nm}$. This is mainly due to the non-functionalized surface and inertness nature of the pure graphite in response toward the radiation. The dramatic changes to the surface morphology and functioning group attached to the graphitic surface layer will promote the absorption of radiation that brought about excitation of outermost electrons into higher energy state. The GO displayed an optical $\pi-\pi^{*}$ aromatic C-C bond absorption band at $231 \mathrm{~nm}$ and a shoulder peak at $300 \mathrm{~nm}$ which responsible to $n-\pi^{*}$ transition of the carbonyl $C=O$ bond [20]. Upon subjected to the AA green reduction, the asprepared $\mathrm{rGO}$ revealed a bathochromic shift absorption at wavelength of $259 \mathrm{~nm}$ indicated the successful restoration of electronic conjugation structure and removal of oxygenated group covalently bonded to the graphene oxide surface $[10,21]$. The $\mathrm{Fe}_{3} \mathrm{O}_{4}$ nanoparticle shows continuous absorption throughout the ultraviolet-visible range of $200 \mathrm{~nm}$ to $80 \mathrm{~nm}$ without any identifiable strong absorption peak. Similarly, the resultant $\mathrm{Fe}_{3} \mathrm{O}_{4} / \mathrm{rGO}$ demonstrated a sharp increment in the optical absorption particularly at near band edge followed by a steady state absorbance approximately at $268 \mathrm{~nm}$ [18]. The redshifted absorption pattern suggested the incorporation of $\mathrm{Fe}_{3} \mathrm{O}_{4}$ onto the surface of graphitic $\mathrm{sp}^{2}$ domain of $\mathrm{rGO}$ which underlying an enhanced photocatalytic performance.

The surface morphology and structural feature of each type of constituents and nanohybrids materials were elucidated through SEM imaging. In Figure 2, GO and rGO demonstrated units of random aggregates with corrugation nature extending over the carbon domain. This unique surface changes was attributed to the chemical destruction and restoration of graphitic $\mathrm{sp}^{2}$ hybridized network happened during intercalation stage and functionalization of graphitic surface [22]. The spontaneous graphitic sheet scrolling is thermodynamically favored, at which the irreversible wrinkle nature of rGO sustains a beneficial high ratio of total surface area to volume [23]. The existences of extra hole defects and vacancies spreading throughout the rGO sheets in comparison to GO is because of the introduction of $\mathrm{sp}^{3}$ oxygenated carbon population and discontinuation of the interplanar $\mathrm{C}-\mathrm{C}$ bonding. This supported that GO was successfully reduced to rGO. The SEM image was obtained for magnetite nanoparticle as shown in Figure 2(d). The magnetite synthesized from co-precipitation appears as sphere-like 
discrete particle with mean size differences in dimension of nanoparticle [24]. The resultant $\mathrm{Fe}_{3} \mathrm{O}_{4} / \mathrm{rGO}$ nanocomposite was shown in Figure 2 (e) with visible discrete outline of both different rGO and MnP nanoparticles. The rGO film was densely anchored with spherical magnetite nanoparticle of uniform size. The crystal growth suppressive effect due interaction of $\mathrm{GO}$ sheet and $\mathrm{Fe}_{3} \mathrm{O}_{4}$ has restrained the extent of $\mathrm{Fe}_{3} \mathrm{O}_{4}$ agglomeration that could facilitate the electron transfer from $\mathrm{Fe}_{3} \mathrm{O}_{4}$ through the $\mathrm{rGO}$ sheet producing an enhanced electrochemical response.

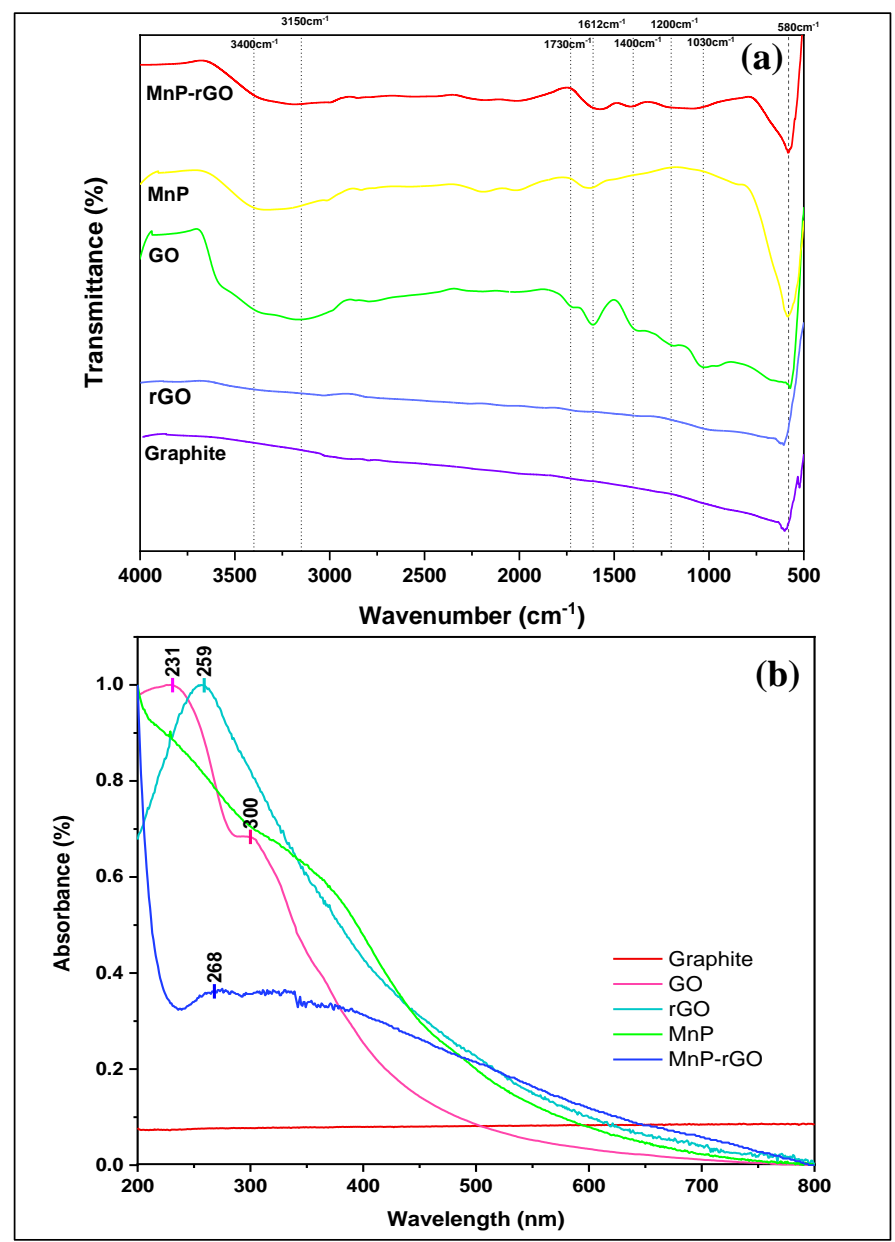

Figure 1. (a) FTIR spectrum and (b) $\mathrm{UV}$-vis spectra of graphite, $\mathrm{GO}, \mathrm{rGO}, \mathrm{Fe}_{3} \mathrm{O}_{4}$ and $\mathrm{Fe}_{3} \mathrm{O}_{4} / \mathrm{rGO}$ nanocomposite 

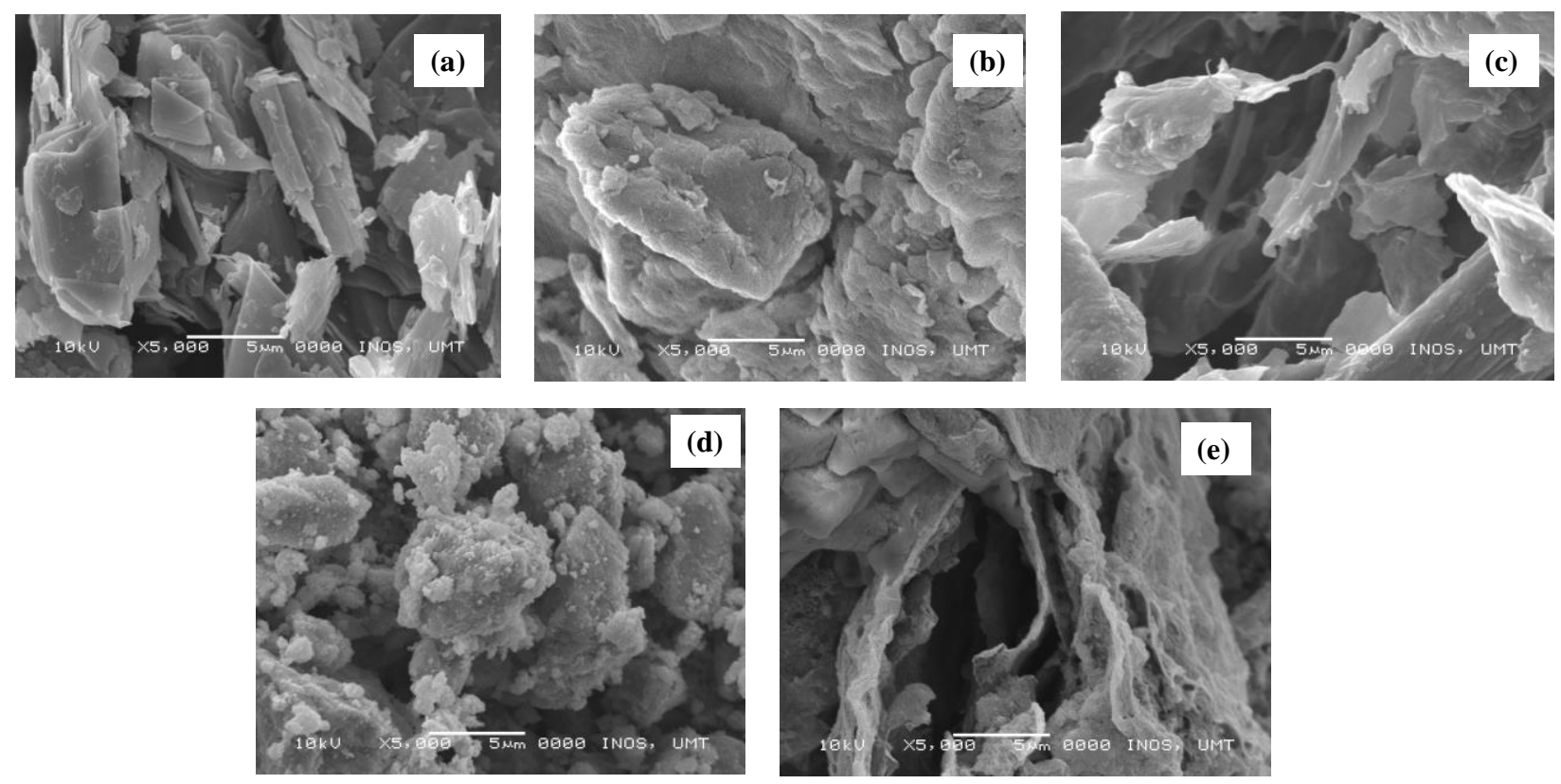

Figure 2. SEM micrographs of (a) graphite, (b) GO, (c) rGO, (d) $\mathrm{Fe}_{3} \mathrm{O}_{4}$, and (e) $\mathrm{Fe}_{3} \mathrm{O}_{4} / \mathrm{rGO}$ with magnification of $\mathrm{x} 5000$ and the operational voltage of $10 \mathrm{kV}$

\section{Electrochemical characterization of $\mathrm{Fe}_{3} \mathrm{O}_{4} / \mathrm{rGO}$}

The electrochemical performance of $\mathrm{Fe}_{3} \mathrm{O}_{4} / \mathrm{rGO}$ was studied using cyclic voltammetry as $\mathrm{Fe}_{3} \mathrm{O}_{4} / \mathrm{rGO} / \mathrm{GCE}$ modified electrode. For comparison purpose, bare GCE, rGO/GCE and $\mathrm{Fe}_{3} \mathrm{O}_{4} / \mathrm{GCE}$ were also studied. Each individual contribution to the observed electrochemical responses were compared in the presence of supporting electrolyte, 1.0 $\mathrm{M} \mathrm{KCl}$ and $5 \mathrm{mM}$ of redox probe agent, $\mathrm{K}_{4}\left[\mathrm{Fe}(\mathrm{CN})_{6}\right]$. The peak potential separation $\left(\Delta \mathrm{E}_{\mathrm{p}}\right)$ and the quasi-reversible behavior of the one-electron redox behavior of $\left[\mathrm{Fe}(\mathrm{CN})_{4}\right]^{3-14-}$ used as indicative measurement in determination of electrode surface improvement. From Figure 3(a), CV measurement on the bare GCE electrode in the presence of $\left[\mathrm{Fe}(\mathrm{CN})_{4}\right]^{3-14}$ couple resulted both anodic $\mathrm{I}_{\mathrm{pa}}$ and cathodic peak current $\mathrm{I}_{\mathrm{pc}}$ at $391.4 \mathrm{~mA}$ and $-384.4 \mathrm{~mA}$, respectively. The $\Delta \mathrm{E}_{\mathrm{p}}$ measured for the bare GCE is $237.6 \mathrm{mV}$. After surface modification of GCE with rGO and $\mathrm{Fe}_{3} \mathrm{O}_{4}$, the voltammetric response generated from both single $\mathrm{Fe}_{3} \mathrm{O}_{4}\left(\mathrm{I}_{\mathrm{pa}}=455.3 \mathrm{~mA}, \mathrm{I}_{\mathrm{pc}}=-433.3 \mathrm{~mA}\right)$ and rGO $\left(\mathrm{I}_{\mathrm{pa}}\right.$ $524.2 \mathrm{~mA}, \mathrm{I}_{\mathrm{pc}}=-531.2 \mathrm{~mA}$ ) coating material which show remarkable peak current increment with a lower $\Delta \mathrm{E}_{\mathrm{p}}$ profile as $219.8 \mathrm{mV}$ and $184.8 \mathrm{mV}$ respectively. The rGO supported $\mathrm{Fe}_{3} \mathrm{O}_{4}$ hybrid composite further enhanced the electrochemical activity, where the anodic and cathodic peak current increase to $629.6 \mathrm{~mA}$ and $-627.4 \mathrm{~mA}$, almost two folds increase compare to bare GCE. This integrated hybrid material dedicated as promising platform of superior conductivity and electrocatalytic performance in sharpening the electrochemical measurement response for electroactive species which describes the $\mathrm{Fe}_{3} \mathrm{O}_{4} / \mathrm{rGO}$ nanocomposites has the narrowest of $\Delta \mathrm{E}_{\mathrm{p}}(157.4 \mathrm{mV})$ among the other materials. The deviation from ideal $\Delta \mathrm{E}_{\mathrm{p}}$ value, $57 \mathrm{mV}$ can be devoted to the incomplete chemical reversibility of redox couple, stability of analyte upon subjected to oxidation and subsequently reduced back to origin state, electron transfer kinetic rate, and existence of interfacial barrier [25]. On the basis of the slope measurement from Randles-Sevcik plot for ferrocyanide oxidation, the linear dependence of peak current, $\mathrm{I}_{\mathrm{pa}}$ on the square root of scan rate can offer quantitative information about the effective surface area (EASA) and diffusion coefficient of the electroactive species. The proportional of Randles-Sevcik slope to the EASA was observed in the order of GCE $>\mathrm{Fe}_{3} \mathrm{O}_{4} / \mathrm{GCE}>\mathrm{rGO} / \mathrm{GCE}>\mathrm{Fe}_{3} \mathrm{O}_{4} / \mathrm{rGO} / \mathrm{GCE}$ as shown in Figure 3 (b). The improved electroactive surface areas of $\mathrm{Fe}_{3} \mathrm{O}_{4} / \mathrm{rGO}$ composite greatly highlights the excellent nature of surface layer deposited on GCE electrode overcome the performance achieved through $\mathrm{rGO}$ and $\mathrm{Fe}_{3} \mathrm{O}_{4}$, individually. Data obtained from $\mathrm{CV}$ information is simplified in Table 1. 


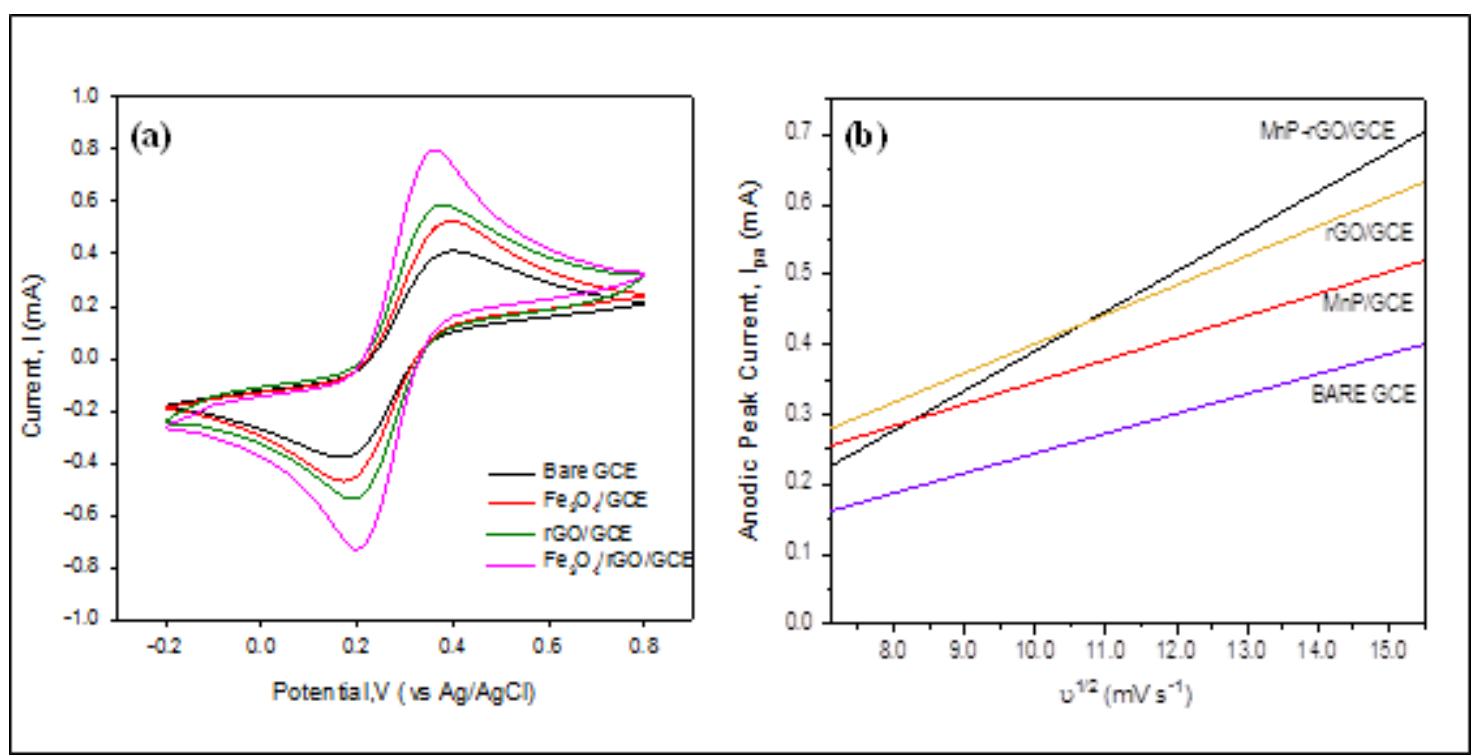

Figure 3. (a) Cyclic voltammogram of bare GCE, GO/GCE, rGO/GCE, $\mathrm{Fe}_{3} \mathrm{O}_{4} / \mathrm{GCE}$, and $\mathrm{Fe}_{3} \mathrm{O}_{4} / \mathrm{rGO} / \mathrm{GCE}$ (b) Randles-Sevcik Plot of different modified electrodes for EASA determination

Table 1. Peak potential separation for bare GCE and modified electrode in the presence of $1.0 \mathrm{M} \mathrm{KCl}$ and $5 \mathrm{mM}$ redox probe solution

\begin{tabular}{lccccccc}
\hline Electrodes & $\begin{array}{c}\mathbf{I}_{\mathbf{p a}}, \\
\boldsymbol{\mu A}\end{array}$ & $\begin{array}{c}\mathbf{I}_{\mathbf{p c}}, \\
\mathbf{\mu A}\end{array}$ & $\begin{array}{c}\mathbf{E}_{\mathbf{p a}}, \\
\mathbf{m V}\end{array}$ & $\begin{array}{c}\mathbf{E}_{\mathbf{p c}}, \\
\mathbf{m V}\end{array}$ & $\begin{array}{c}\Delta \mathbf{E}_{\mathbf{p}}, \\
\mathbf{m V}\end{array}$ & $\begin{array}{c}\text { Slope } \\
\left.\mathbf{( 1 0}^{-5}\right)\end{array}$ & $\begin{array}{c}\mathbf{E A S A}, \mathbf{c m}^{-2} \\
\left.\mathbf{( 1 0}^{-6}\right)\end{array}$ \\
\hline $\mathrm{GCE}$ & 391.4 & -384.4 & 409.9 & 172.3 & 237.6 & 2.84 & 8.48 \\
$\mathrm{Fe}_{3} \mathrm{O}_{4} / \mathrm{GCE}$ & 455.3 & -433.3 & 394.8 & 175.0 & 219.8 & 3.16 & 9.42 \\
$\mathrm{rGO} / \mathrm{GCE}$ & 524.2 & -531.2 & 379.7 & 194.9 & 184.8 & 4.20 & 12.5 \\
$\mathrm{Fe}_{3} \mathrm{O}_{4} / \mathrm{rGO} / \mathrm{GCE}$ & 629.6 & -627.4 & 359.8 & 202.3 & 157.4 & 5.69 & 17.0 \\
\hline
\end{tabular}

\section{Electrochemical performance of $\mathrm{Fe}_{3} \mathrm{O}_{4} / \mathrm{rGO} / \mathrm{GCE}$ in the presence of $\mathrm{UA}$}

The voltammetric responses of the $\mathrm{Fe}_{3} \mathrm{O}_{4} / \mathrm{rGO} / \mathrm{GCE}$ toward UA detection and its application in different sensing environment was studied in the $0.1 \mathrm{M}$ PBS buffer solution of $\mathrm{pH} 7$ containing $400 \mu \mathrm{M}$ UA analyte. The electron transfer behavior through different sensing interface of electrode was studied using the same instrument configuration and parameter setups. The cyclic voltammograms of various modified electrodes in Figure 4 revealed the electrocatalytic performance of $\mathrm{Fe}_{3} \mathrm{O}_{4} / \mathrm{rGO}$ nanocomposite coated GCE outstands the other surface-modifed electrode. There was a minor difference in the anodic peak potential for the UA oxidation on various surface modified electrode. However, the rGO/GCE shows a higher current background baseline at the end of forward scan. This baseline signals was refined on the proposed $\mathrm{Fe}_{3} \mathrm{O}_{4} / \mathrm{rGO} / \mathrm{GCE}$, which assumed due to the depleted electrical double layer (EDL), and capacitance current accumulated at the charged electrode. The anodic peak current has been improved as much as $1.65 \mu \mathrm{A}(81.28 \%)$ compared to bare GCE under the same $50 \mathrm{mVs}^{-1}$ scan rate. The increment in the anodic peak current, $\mathrm{I}_{\mathrm{pa}}$ was parallel to the calculated diffusion coefficient using the RandlesSevcik equation shown in equation 1.

$$
\mathrm{I}_{\mathrm{P}}=\left(2.69 \times 10^{5}\right) \mathrm{n}^{3 / 2} \mathrm{~A} \mathrm{D}^{1 / 2} \mathrm{C} \mathrm{V}
$$

where $\mathrm{n}$ is the number of electron taking part in the redox reaction $(\mathrm{n}=2), \mathrm{A}$ is the electroactive surface $\operatorname{area}, \mathrm{cm}^{2}(\mathrm{~A}$ $=0.08 \mathrm{~cm}^{2}$ respect to GCE), D as the diffusion coefficient, $\mathrm{c}$ is the bulk concentration, $\mathrm{mol} \mathrm{cm}^{-3}\left(\mathrm{c}=4 \mathrm{X} 10^{-4} \mathrm{~mol}\right.$ $\left.\mathrm{cm}^{-1}\right)$ and scan rate, $\mathrm{V} \mathrm{s}^{-1}\left(\mathrm{v}=0.05 \mathrm{~V} \mathrm{~s}^{-1}\right)$ is denoted by $\mathrm{v}$. 
The $\mathrm{Fe}_{3} \mathrm{O}_{4} / \mathrm{rGO} / \mathrm{GCE}$ modified electrode stands a better diffusivity $\left(\mathrm{D}=4.57 \times 10^{-13} \mathrm{~cm}^{2} \mathrm{~s}^{-1}\right.$ ) compared to another modified electrode. Thus, it do allows faster rate of mass transport for UA molecules diffuses across the concentration gradient and bulk solution molecules near the surface of electrode in a voltammetric detection. The cyclic voltammogram of UA in 0.1 M PBS buffer solution show a typical observation, where only one anodic peak was recognized. It expressing that the undergoing reaction is of irreversible for UA reduction. This can be attributed to the characteristic of UA and its possible alternative oxidation pathway of the electrode process demonstrated in the Figure 4 (inset) [26]. The primary partially oxidized UA product is composed of 4,5-dihydroxyluric acid, which is liable to oxidative degradation in favor the formation of chemically stable allantoin molecules. The diffusion coefficient results from bare GCE and different surface-modified electrodes summarized in Table 2.

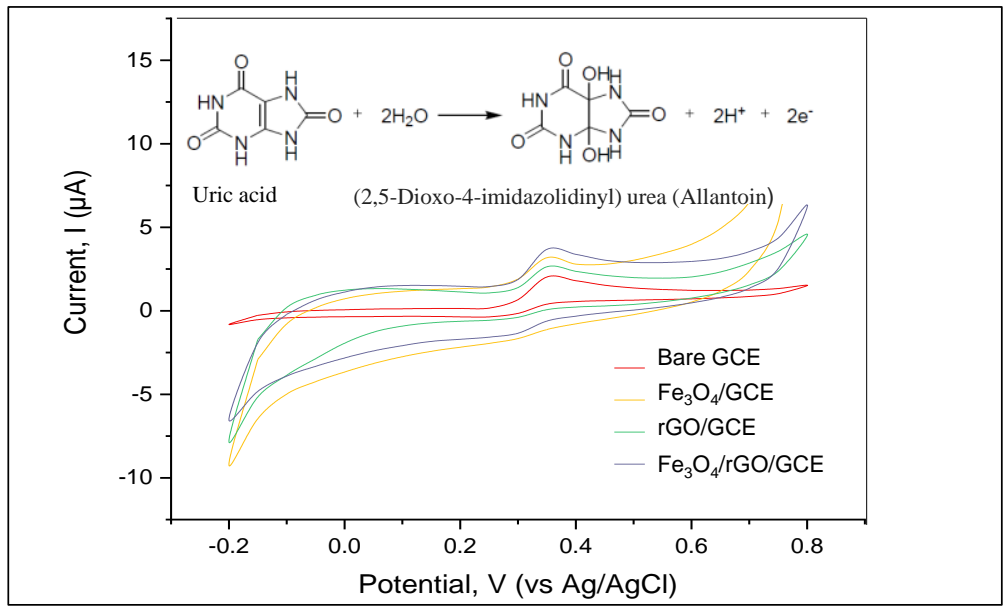

Figure 4. Cyclic voltammetric response of different surface-modified electrode in 400uM UA containing 0.1M PBS buffer solution ( $\mathrm{pH} 7$ )

Table 2. The diffusion coefficient results from bare GCE and different surface-modified electrodes in 0.1M PBS solution $(\mathrm{pH}=7)$ containing $400 \mu \mathrm{M} \mathrm{UA}$

\begin{tabular}{lccc}
\hline Material (s) & $\begin{array}{c}\text { Anodic Peak Potential, } \\
\mathbf{E}_{\mathbf{p a}}(\mathbf{V})\end{array}$ & $\begin{array}{c}\text { Anodic Peak current, } \\
\mathbf{I}_{\mathbf{p a}}(\boldsymbol{\mu} \mathbf{A})\end{array}$ & $\begin{array}{c}\text { Diffusion Coefficient, } \\
\mathbf{D}\left(\mathbf{c m}^{\mathbf{2}} \mathbf{~ s}^{-\mathbf{1}}\right) /\left(\mathbf{1 0}^{-\mathbf{1 3}}\right)\end{array}$ \\
\hline $\mathrm{Bare} \mathrm{GCE}$ & 0.35 & 2.03 & 1.39 \\
$\mathrm{rGO}$ & 0.35 & 3.18 & 3.42 \\
$\mathrm{Fe}_{3} \mathrm{O}_{4}$ & 0.35 & 2.64 & 2.35 \\
$\mathrm{Fe}_{3} \mathrm{O}_{4}-\mathrm{rGO}$ & 0.35 & 3.68 & 4.57 \\
\hline
\end{tabular}

The optimum condition used to investigate the electrochemical behavior of UA was then performed based on the three parameters chosen for voltammetric detection purpose. The effect of scan rate, analyte concentration and $\mathrm{pH}$ of the supporting electrolyte were focused for any enhancement effect in the UA oxidation signal. The improved signal to noise ratio can be helpful in defining the UA content in the urine sample, which can be said equally important in recovery, precision and accuracy study that accounts for the repeatability as well as reproducibility. The conventional 3-electrode system was applied in parameter optimization with modified electrode $\mathrm{Fe}_{3} \mathrm{O}_{4} / \mathrm{rGO} / \mathrm{GCE}$ as the working electrode and a $2 \mathrm{~mm}$ diameter platinum rod dedicated as counter electrode in complement to silver/silver chloride, $\mathrm{Ag} / \mathrm{AgCl}(\mathrm{KCl}=3.0 \mathrm{M})$.

The scan rate selected for cyclic voltammetry detection of UA ranging from $50 \mathrm{mVs}^{-1}$ to $250 \mathrm{mVs}^{-1}$ with a $50 \mathrm{mVs}^{1}$ as the increment constant at each running cycles $(n=6)$. The instrument calibration factor and diagnostic test was 
performed before running the experiment. The electroanalysis profile selected in procedure and configuration was fixed with $5 \mathrm{mV}$ step potential and starting potential of $0.15 \mathrm{~V}$. The cyclic voltammogram displayed in Figure $5(\mathrm{a})$ revealed the effect of scan rate variation on the peak current recorded for the UA oxidation process. Table 3 depicted that increasing the scan rate from $50 \mathrm{mVs}^{-1}$ to $250 \mathrm{mVs}^{-1}$ positively shifts the peak potential from $0.356 \mathrm{~V}$ to $0.367 \mathrm{~V}$. Correspondingly, the scan rate variation increases linearly with the diffusion coefficient, D calculated that facilitated the flux movement and diminishing of diffusion layer grow in an electrode process. This gradually shift in peak potential ascribed to UA oxidation implying the consequence of kinetic limitation happened between the active edges of the $\mathrm{Fe}_{3} \mathrm{O}_{4} / \mathrm{rGO}$ decorated on the GCE surface and UA molecules [24]. The linearity relationship between the peak current value recorded and variation of scan rate defined the characteristic of a surface adsorptionlimiting process [27].

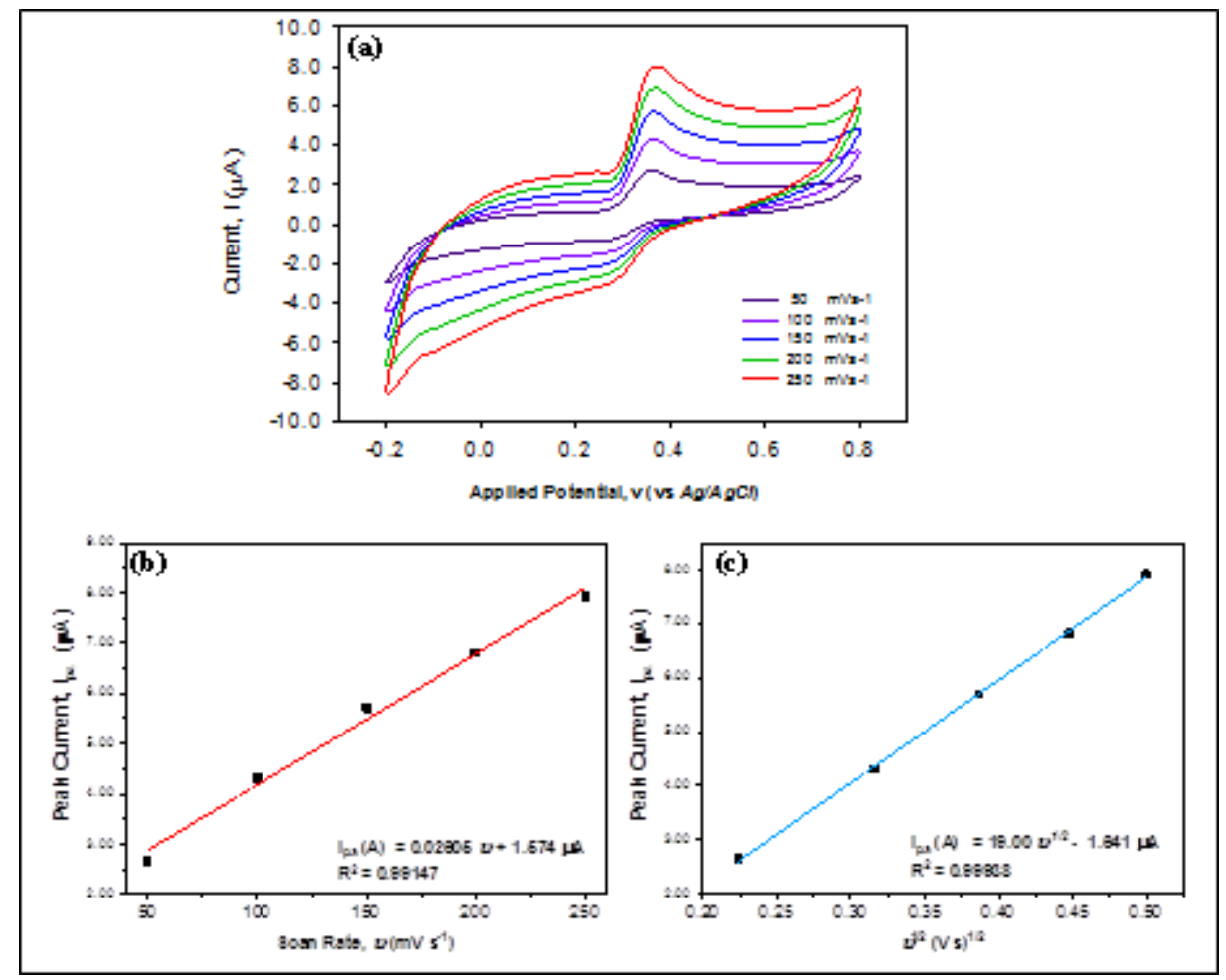

Figure 5. (a) Cyclic voltammogram of $400 \mu \mathrm{M}$ UA standard measured at different scan rate (50-250mVs- ${ }^{1}$ ) and (b) Plot of peak current against scan rate and (c) Randles-Sevcik plot for diffusion coeffient determination

Table 3. Scan rate variations and its related properties measurement result

\begin{tabular}{lcccc}
\hline $\begin{array}{l}\text { Scan } \\
\text { Rate } \\
\left(\mathbf{m V ~ s}^{-\mathbf{1}}\right)\end{array}$ & $\begin{array}{c}\text { Anodic Peak } \\
\text { Potential, } \\
\mathbf{E}_{\mathbf{p a}}(\mathbf{v})\end{array}$ & $\begin{array}{c}\text { Anodic Peak } \\
\text { Current, } \\
\mathbf{I}_{\mathbf{p a}}(\mathbf{A}) /\left(\mathbf{1 0}^{-\mathbf{6}}\right)\end{array}$ & $\begin{array}{c}\text { Square Root of } \\
\text { Scan Rate } \\
\left(\mathbf{V}^{\mathbf{1 / 2}} \mathbf{s}^{-\mathbf{1 / 2}}\right)\end{array}$ & $\begin{array}{c}\text { Diffusion } \\
\text { Coefficient } \\
\left(\mathbf{c m}^{\mathbf{2}} \mathbf{s}^{-\mathbf{1}}\right) /\left(\mathbf{1 0}^{-\mathbf{1 3}}\right)\end{array}$ \\
\hline 50 & 0.356 & 2.65 & 0.224 & 2.378 \\
100 & 0.359 & 4.32 & 0.316 & 6.290 \\
150 & 0.362 & 5.70 & 0.387 & 10.97 \\
200 & 0.364 & 6.81 & 0.447 & 15.66 \\
250 & 0.367 & 7.92 & 0.500 & 21.17 \\
\hline
\end{tabular}


The Figure 5(b) displayed the peak current is directly proportional to the scan rate with a linear regression equation of $\mathrm{I}_{\mathrm{pa}}(\mathrm{A})=2.605 \times 10^{-8} \mathrm{v}+1.574 \times 10^{-6}, \mathrm{R}^{2}=0.99147$. Meanwhile, another identical relationship was illustrated in Figure 5 (c) which is a Randles-Revcik plot useful in effective surface area (EASA) and diffusion coefficient, D of a substrate molecule. A higher proportional linearity $\left(\mathrm{R}^{2}=0.99938\right)$ relationship was identified in the plots of anodic peak current $\left(\mathrm{I}_{\mathrm{pa}}\right)$ against square root of scan rate variation $\left(\mathrm{v}^{1 / 2}\right)$ under the studied range of scan rate. The obtained regression equation $\mathrm{I}_{\mathrm{pa}}(\mathrm{A})=1.9 \times 10^{-5} \mathrm{v}^{1 / 2}-1.641 \times 10^{-6}$ with correlation coefficient nearly to unity suggested the UA oxidation over the $\mathrm{Fe}_{3} \mathrm{O}_{4} / \mathrm{rGO} / \mathrm{GCE}$ surface was diffusion-limiting dominated over the adsorption-controlled mechanism [28]. These results provided that the mass transfer or absorption controlled process of UA oxidation take place at the low scan rate instead of diffusion-limiting dominated at high scan rate [29]. The scan rate $50 \mathrm{mVs}^{-1}$ was selected for the further part of the optimization where its peak potential was nearly to the zero. In view of the current response of UA is being diffusion controlled, a slower scan rate will allow the UA molecules diffuses through the bulk electrolyte toward the electrode surface. Even though there will be growth in the diffusion layer, it provides certain degrees of sensitivity and stability about the variation in peak current and peak-to-peak separation especially in the study of $\mathrm{pH}$ parameter optimization.

A series of UA standard concentration was selected within range from $100 \mu \mathrm{M}$ to $800 \mu \mathrm{M}$. The experiment was designed to run 6 cycles simultaneously at $50 \mathrm{mVs}^{-1}$ scan rate with a magnitude of $0.05 \mathrm{~V}$ step potential sweeping from initial potential $-0.2 \mathrm{~V}$ to end potential $0.8 \mathrm{~V}$. The reagent and standard preparations were kept constant as described previously. The step up current responses obtained from the increasing concentration of UA show a corresponding contribution of faradaic current from higher electroactive species in an electrode process. The respectively current response and peak potential variation according to the amount of UA introduced was tabulated in Table 4.

Table 4. Result of anodic peak potentials and peak currents at various UA concentrations (100-800 $\mu \mathrm{M})$

\begin{tabular}{lcc}
\hline $\begin{array}{l}\text { Concentration } \\
(\mathbf{s})\end{array}$ & $\begin{array}{c}\text { Anodic Peak Potential, } \\
\mathbf{I}_{\mathbf{p a}}(\mathbf{V})\end{array}$ & $\begin{array}{c}\text { Anodic Peak Current, } \\
\mathbf{I}_{\mathbf{p c}}(\boldsymbol{\mu} \mathbf{A})\end{array}$ \\
\hline 100 & 0.35 & 1.23 \\
200 & 0.35 & 1.65 \\
400 & 0.35 & 2.69 \\
600 & 0.35 & 3.47 \\
800 & 0.35 & 4.59 \\
\hline
\end{tabular}

Based on the cyclic voltammogram result in Figure 6(a), the peak potential being unchanged for five successive different UA standard measurements at constant scan rate and experimental condition. This reflects good stability and accountability in measuring the current responses originated from various UA standard concentrations in suggested cyclic voltammetry technique. The calibration curve was plotted against the concentration of UA ranging from $100 \mu \mathrm{M}$ to $800 \mu \mathrm{M}$ provided a good fitting of data with correlation coefficient equal to 0.99711 . The linearity behavior of UA concentration and anodic peak currents can be expressed as $\mathrm{I}_{\mathrm{pa}}(\mathrm{A})=4.757 \times 10^{-9} c+7.270 \times 10^{-7}$, as shown in the Figure 6 (b). The highest current achieved was $4.59 \mu \mathrm{A}$ correspondingly to the highest upper limit of UA concentration, which is $800 \mu \mathrm{M}$ and the trend then followed in descending order of $600 \mu \mathrm{M}(3.47 \mu \mathrm{A})<400$ $\mu \mathrm{M}(2.69 \mu \mathrm{A})<200 \mu \mathrm{M}(1.65 \mu \mathrm{A})<100 \mu \mathrm{M}(1.23 \mu \mathrm{A})$. The result obtained implies that the $\mathrm{Fe}_{3} \mathrm{O}_{4} / \mathrm{rGO}$ nanocomposite manage to electrocatalyze the UA oxidation meanwhile current transport at the electrode surface facilitated by gapless conducting material of rGO due excellent electron conductivity $[1,7]$. The preferential concentration for the following research purpose was chosen $400 \mu \mathrm{M}$, which is the intermediate value at full concentration range of UA studied. It gives sharp and well-defined oxidative current peak of considerable good sensitivity and peak resolution. 


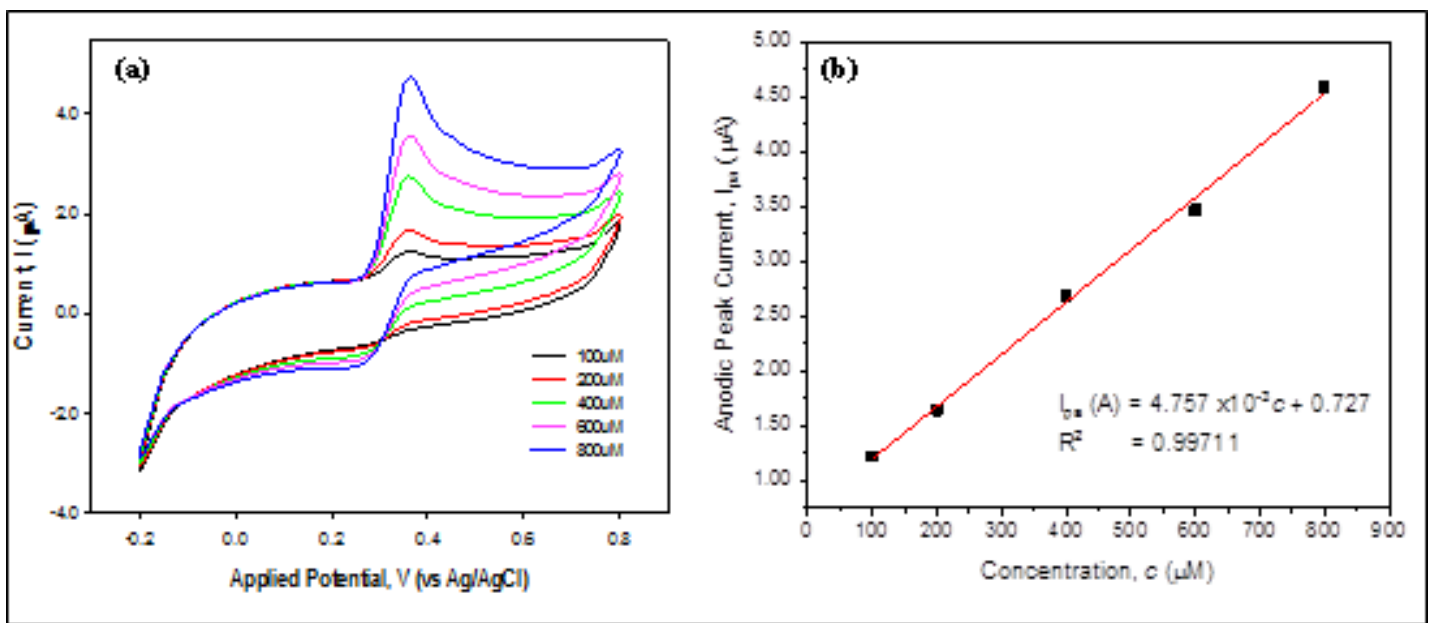

Figure 6. (a) Cyclic voltammetry measurements at various concentrations ranging from $100 \mu \mathrm{M}$ to $500 \mu \mathrm{M}$ of UA standard solution and (b) Calibration curve of anodic peak current against UA concentration $(100-800 \mu \mathrm{M})$

The effect of supporting electrolyte (PBS buffer solution) $\mathrm{pH}$ on the CV and DPV response of $400 \mu \mathrm{M}$ UA were conducted by varying the $\mathrm{pH}$ from 4.0 to 9.0 . The changes to the chemical environment surrounding the UA molecules in reaction of electrochemical oxidation was investigated in term of peak current and potential as well as the charging effect due electrolyte properties. Refers to Figure 7(a) and (b), the anodic peak potential shifts negatively as $\mathrm{pH}$ varying from 4.0 to 9.0 in both CV and DPV measurement. The DPV displays even higher sensitivity and selectivity as compared to typical CV technique due slow decay rate of capacitance current and nonfaradaic current corresponds to the background current. These profound negative shifts suggested that the redox reaction of $\mathrm{UA}$ involved proton transferred at the $\mathrm{Fe}_{3} \mathrm{O}_{4}-\mathrm{rGO}$ modified electrode. The $\mathrm{pH}$ changes will affects the adsorption performance of $\mathrm{Fe}_{3} \mathrm{O}_{4} / \mathrm{rGO}$, which can be rationalized based on the charge accumulation on the electroactive surface sites, degree of ionization of analyte, electrostatic repulsion or attraction between analyte and functionalized electrode surface $[14,30]$.

The uric acid solubilized in alkalizing solution presented majorly as deprotonated urate bearing an overall negative charged surface was repelled from redox site dominated by hydroxyl groups. Similarly, changes the pH from alkaline to acidic will neutralized the negative charged urate as non-ionized uric acid and the electrostatic attraction between the UA and $\mathrm{Fe}_{3} \mathrm{O}_{4}$-rGO/GCE surface was strengthen [31]. Figure 7(c), the $\mathrm{pH}$ selected was 7.0, which is neutral and assembles to normal urine $\mathrm{pH}$ of 6.0 to 7.5. The peak current measured in both CV and DPV techniques revealed that the $\mathrm{pH}$ selected is stable and high sensitivity in view of high peak currents and negligible interference. The results obtained was summarized in Table 5. The plot of anodic peak potential versus $\mathrm{pH}$ in Figure 7(d) expressed linearity $\left(\mathrm{R}^{2}=0.99509\right)$ in the $\mathrm{pH}$ range of 4 to 9 with a slope of $-56 \mathrm{mV} \mathrm{pH}^{-1}$, which closely approximate to the theoretical Nernst equation value $\left(-59 \mathrm{mV} \mathrm{pH}^{-1}\right)$. This again implies that the electrochemical oxidation of UA involves an equivalent number $(n=2)$ of electron and proton [24, 31]. 


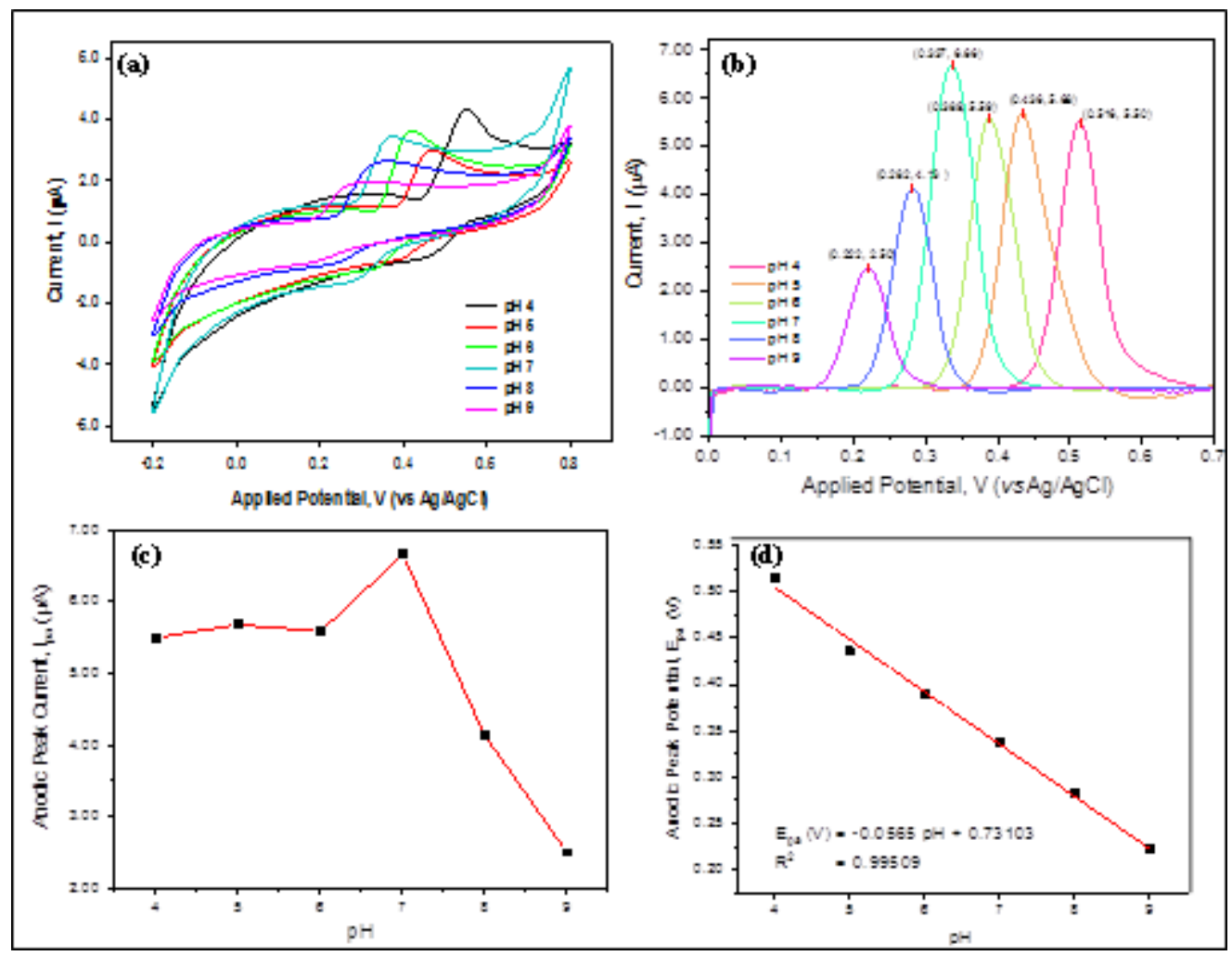

Figure 7. (a) Influences of electrolyte $\mathrm{pH}$ on the oxidative peak current of UA in cyclic voltammogram, (b) DPV response toward UA determination according to $\mathrm{pH}$ changes from 4.0 to 9.0, (c) Plot of peak current against $\mathrm{pH}$ value of the supporting electrolyte (0.1M PBS solution) and (d) Plot of anodic peak potential against $\mathrm{pH}$ value of the supporting electrolyte (0.1M PBS solution)

Table 5. Peak current and potential values correspond to the $\mathrm{pH}$ variation

\begin{tabular}{ccccc}
\hline \multirow{2}{*}{$\mathbf{p H}$} & \multicolumn{2}{c}{ Cycic voltmammetric Response(s) } & \multicolumn{2}{c}{ Differential Pulse Voltammetric Response $(\mathbf{s})$} \\
\cline { 2 - 5 } & $\begin{array}{c}\text { Peak Potential, } \\
\mathbf{E}_{\mathbf{p}}(\mathbf{V})\end{array}$ & $\begin{array}{c}\text { Peak Current, } \\
\mathbf{I}_{\mathbf{p}}(\boldsymbol{\mu} \mathbf{A})\end{array}$ & $\begin{array}{c}\text { Peak Potential, } \\
\mathbf{E}_{\mathbf{p}}(\mathbf{V})\end{array}$ & $\begin{array}{c}\text { Peak Current, } \\
\mathbf{I}_{\mathbf{p}}(\boldsymbol{\mu} \mathbf{A})\end{array}$ \\
\hline 4 & 0.553 & 4.34 & 0.515 & 5.50 \\
5 & 0.470 & 3.03 & 0.436 & 5.68 \\
6 & 0.424 & 3.64 & 0.389 & 5.59 \\
7 & 0.373 & 3.48 & 0.337 & 6.66 \\
8 & 0.337 & 2.57 & 0.282 & 4.13 \\
9 & 0.262 & 1.79 & 0.222 & 2.50 \\
\hline
\end{tabular}

Limit of detection (LOD) and Limit of Quantification (LOQ)

The LOD and LOQ calculated are $3.04 \mu \mathrm{M}$ and $10.14 \mu \mathrm{M}$, respectively, which is comparable, excellent and suitable for UA content determination compared to the previous study tabulated in Table 6. 
Table 6. Comparison of current work with the previous study of uric acid determination

\begin{tabular}{llcl}
\hline Electrode & $\begin{array}{l}\text { Detection } \\
\text { Method }\end{array}$ & $\begin{array}{c}\text { Detection Limit } \\
(\mu \mathbf{M})\end{array}$ & References \\
\hline Pani/AuNPs & DPV & 20.0 & {$[32]$} \\
$\mathrm{ZnO} / \mathrm{rGO}$ & $\mathrm{DPV}$ & 8.5 & {$[33]$} \\
$\mathrm{AgNPs} / \mathrm{rGO}$ & $\mathrm{DPV}$ & 8.2 & {$[34]$} \\
$\mathrm{Modified} \mathrm{GCE}(0.5 \mathrm{M} \mathrm{NaOH}$ solution $)$ & $\mathrm{DPV}$ & 4.7 & {$[35]$} \\
$\mathrm{Fe}_{3} \mathrm{O}_{4} / \mathrm{rGO}$ & $\mathrm{DPV}$ & 3.04 & Current work \\
\hline
\end{tabular}

Additionally, the current response proportional increases with the UA concentration added into the phosphate buffer solution of $\mathrm{pH}$ 7. In the lower range of concentration, the linear regression equation obtained was $\mathrm{I}_{\mathrm{pa}}(\mathrm{A})=8.477$ $\times 10^{-8} c+8.43743 \times 10^{-6}$ with a correlation coefficient of 0.989 and sensitivity of $0.08478 \mu \mathrm{A} / \mu \mathrm{M}$. In the second linear dynamic segment, the linearity was expressed as $\mathrm{I}_{\mathrm{pa}}(\mathrm{A})=6.631 \times 10^{-9} c+1.65937 \times 10^{-5}$ with a $\mathrm{R}^{2}=0.953$ correspond to higher UA concentration ranging from $100 \mu \mathrm{M}$ to $800 \mu \mathrm{M}$ (Figure 8b). The declination in sensitivity (slope) at higher magnitude of concentration was described by the kinetic limitation of electroactive species toward the $\mathrm{Fe}_{3} \mathrm{O}_{4} / \mathrm{rGO} / \mathrm{GCE}$ surface in a transport mechanism [7, 36]. A surge amount of oxidation products inhibits the adsorption site for electrocatalytic oxidation of UA, thereby resulting lower down the electrode response sensitivity to $0.00663 \mu \mathrm{A} / \mu \mathrm{M}$.

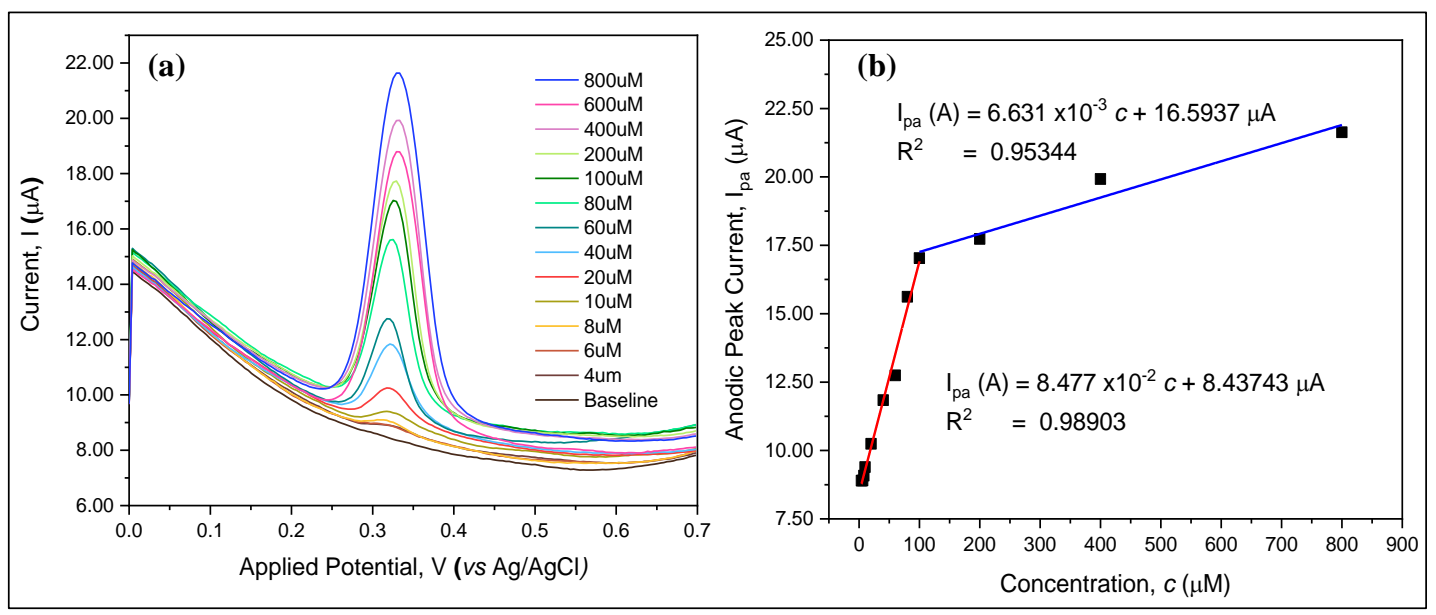

Figure 8. (a) DPV response measured over a range of UA concentration from $0 \mu \mathrm{M}$ to $800 \mu \mathrm{M}$ and (b) The relationship between the oxidation peaks current against UA concentration $(4-800 \mu \mathrm{M})$

\section{Conclusion}

The $\mathrm{Fe}_{3} \mathrm{O}_{4} / \mathrm{rGO}$ hybrid material had successfully synthesized through one facile reduction of $\mathrm{GO}$ and coprecipitation of $\mathrm{Fe}_{3} \mathrm{O}_{4}$ which accounts for high percentage yield of product, cost effectiveness and being environmental green catalytic composite. The enhanced electrocatalytic performance of the $\mathrm{Fe}_{3} \mathrm{O}_{4} / \mathrm{rGO} / \mathrm{GCE}$ electrode provides a comprising potential in voltammetry determination of physiologically related molecules such as ascorbic acid and dopamine. The Cyclic Voltammetry (CV) result in the previous part has revealed the improved electronic properties of the resultant nanocomposite in term of the low resistivity, rapid electron transfer, and well defined peak resolution as well as peak separation. In additional, the physical properties of as-synthesized $\mathrm{Fe}_{3} \mathrm{O}_{4} / \mathrm{rGO}$ nanocomposite was successfully investigated by various characterization techniques, including Fourier Transform Infrared Spectroscopy (FTIR), Ultraviolet-visible Spectroscopy (UV-Vis), Scanning Electron 
Microscopy (SEM). The Differential Pulse Voltammetry (DPV) was used in complementary to the application CV and EIS in electrochemically characterization of $\mathrm{Fe}_{3} \mathrm{O}_{4} / \mathrm{rGO}$ nanocomposite. The $\mathrm{Fe}_{3} \mathrm{O}_{4}$-rGO/GCE sensing electrode exhibits high selectivity and sensitivity in UA oxidation with low detection limit of $3.04 \mu \mathrm{M}$. The results suggested the great potential use of $\mathrm{Fe}_{3} \mathrm{O}_{4} / \mathrm{rGO} / \mathrm{GCE}$ in selectively non-enzymatic sensing of UA as compared to conventional UA determination such as chromogen-dependent colorimetric method and enzymatic technique by uricase.

\section{Acknowledgement}

The authors are grateful to Fundamental Research Grant Scheme (FRGS) FRGS/1/2017/STG01/UMT/02/2 for financial support as well as Universiti Malaysia Terengganu for providing facilities for undertaking this research.

\section{References}

1. Wang, H., Ren, F., Wang, C., Yang, B., Bin, D., Zhang, and Du, Y. (2014). Simultaneous determination of dopamine, uric acid and ascorbic acid using a glassy carbon electrode modified with reduced graphene oxide. RSC Advances, 4(51): 26895-26901.

2. So, A. and Thorens, B. (2010). Science in medicine uric acid transport and disease. The Journal of Clinical Investigation, 120(6): 1791-1799.

3. Muraoka, S. and Miura, T. (2003). Inhibition by uric acid of free radicals that damage biological molecules. Pharmacology and Toxicology. 93 (6): 284-289.

4. Lavanya, N., Fazio, E., Neri, F., Bonavita, A., Leonardi, S.G., Neri, G. and Sekar, C. (2015). Simultaneous electrochemical determination of epinephrine and uric acid in the presence of ascorbic acid using $\mathrm{SnO}_{2}$ graphene nanocomposite modified glassy carbon electrode. Sensors and Actuators B: Chemical, 221: 14121422 .

5. Jiang, J. and Du, X. (2014). Sensitive electrochemical sensors for simultaneous determination of ascorbic acid, dopamine, and uric acid based on Au@Pd-reduced graphene oxide nanocomposites. Nanoscale, 6 (19): 1130311309.

6. Teymourian, H., Salimi, A. and Khezrian, S. (2013). $\mathrm{Fe}_{3} \mathrm{O}_{4}$ Magnetic nanoparticles/reduced graphene oxide nanosheets as a novel electrochemical and bioeletrochemical sensing platform. Biosensors and Bioelectronics, 49: $1-8$.

7. Peik-See, T., Pandikumar, A., Nay-Ming, H., Hong-Ngee, L. and Sulaiman, Y. (2014). Simultaneous electrochemical detection of dopamine and ascorbic acid using an iron oxide/reduced graphene oxide modified glassy carbon electrode. Sensors, 14(8): 15227-15243.

8. Zheng, D., Hu, H., Liu, X. and Hu, S. (2015). Application of graphene in elctrochemical sensing. Current Opinion in Colloid and Interface Science, 20 (5-6): 383-405.

9. Chandra, V., Park, J., Chun, Y., Lee, J. W., Hwang, I. C. and Kim, K. S. (2010). Water-dispersible magnetitereduced graphene oxide composites for arsenic removal. ACS Nano, 4(7): 3979-3986.

10. Farghali, M., Material, A., Salah, T. and Al-enizi, A. M. (2014). Graphene/magnetite nanocomposite for potential environmental application. International Journal of Electrochemical Sciences, 10: 529-537.

11. Yusoff, F., Ngai, T. Z., Chai, C. H. and Lee, P. S. (2018). The electrochemical behavior of zinc oxide/ reduced graphene oxide composite electrode in dopamine. Malaysian Journal of Analytical Sciences, 22 (2): 227-237.

12. Andrijanto, E., Shoelarta, S., Subiyanto, G. and Rifki, S. (2016). Facile synthesis of graphene from graphite using ascorbic acid as reducing agent. AIP Conference Proceedings. 1725: 020003.

13. Yusoff, F. and Mohamed, N. B. (2018). The physical and electrochemical characteristic of gold nanoparticles supported pedot/graphene composite as potential cathode material in fuel cells. Malaysian Journal of Analytical Sciences, 22(6): 921-930.

14. Thi, N., Hoan, V., Thu, A., Duc, H. Van, Cuong, N. D., Khieu, D. Q.,Vo, V., Vuong, N. T. and Vn, H. (2016). $\mathrm{Fe}_{3} \mathrm{O}_{4} /$ reduced graphene oxide nanocomposite: Synthesis and its application for toxic metal ion removal. Journal of Chemistry, 2016: 1-10.

15. Mahmood, H., Habib, A., Mujahid, M., Tanveer, M., Javed, S. and Jamil, A. (2014). Band gap reduction of titania thin films using graphene nanosheets. Materials Science in Semiconductor Processing, 24(1): 193-199.

16. Wang, A., Yu, W., Huang, Z., Zhou, F., Song, J., Song, Y., Long, L., Cifuentes, M. P., Humphrey, M. G., Zhang, L., Shao, J. and Zhang, C. (2016). Covalent functionalization of reduced graphene oxide with porphyrin by means of diazonium chemistry for nonlinear optical performance. Scientific Reports, 6: 1-12. 
17. Li, Q., Kartikowati, C. W., Horie, S., Ogi, T., Iwaki, T. and Okuyama, K. (2017). Correlation between particle size/domain structure and magnetic properties of highly crystalline $\mathrm{Fe}_{3} \mathrm{O}_{4}$ nanoparticles. Scientific Reports, 7(1): $1-4$.

18. Rajput, S., Pittman, C. U., and Mohan, D. (2016). Magnetic magnetite $\left(\mathrm{Fe}_{3} \mathrm{O}_{4}\right)$ nanoparticle synthesis and applications for lead $\left(\mathrm{Pb}^{2+}\right)$ and chromium $\left(\mathrm{Cr}^{6+}\right)$ removal from water. Journal of Colloid and Interface Science, 468: 334-346.

19. Kamakshi, T., Sundari, G. S., Erothu, H. and Rao, T. P. (2018). Synthesis and characterization of graphene based iron oxide $\left(\mathrm{Fe}_{3} \mathrm{O}_{4}\right)$ nanocomposites. Rasayan Journal of Chemistry, 11(3): 1113-1119.

20. Yang, S., Yue, W., Huang, D., Chen, C., Lin, H. and Yang, X. (2012). A facile green strategy for rapid reduction of graphene oxide by metallic zinc. RSC Advances, 2(23): 8827-8832.

21. Xue, Y., Chen, H., Yu, D., Wang, S., Yardeni, M., Dai, Q., Guo, M., Liu Y., Lu, F., Qu, J. and Dai, L. (2011). Oxidizing metal ions with graphene oxide: the in situ formation of magnetic nanoparticles on self-reduced graphene sheets for multifunctional applications. Chemical Communications, 47(42): 11689-11691.

22. Dimiev, A. M. and Tour, J. M. (2014). Mechanism of graphene oxide formation. ACS Nano, 8 (3): 3060-3068.

23. Aneesh, P. K., Nambiar, S. R., Rao, T. P. and Ajayaghosh, A. (2014). Electrochemically synthesized partially reduced graphene oxide modified glassy carbon electrode for individual and simultaneous voltammetric determination of ascorbic acid, dopamine and uric acid. Analytical Methods, 6(14): 5322-5330.

24. Hariani, P.L., Faizal, M., Ridwan, R., Marsi, M., and Setiabudidaya, D. (2013). Synthesis and Properties of $\mathrm{Fe}_{3} \mathrm{O}_{4}$ Nanoparticles by Co-precipitation Method to Removal Procion Dye. International Journal of Environmental Science and Development. 4 (3): 336-340.

25. Elgrishi, N., Rountree, K. J., McCarthy, B. D., Rountree, E. S., Eisenhart, T. T., and Dempsey, J. L. (2018). A practical beginner's guide to cyclic voltammetry. Journal of Chemical Education, 95(2): 197-206.

26. Chao, M., Ma, X. and Li, X. (2012). Graphene-modified electrode for the selective determination of uric acid under coexistence of dopamine and ascorbic acid. International Journal of Electrochemical Science, 7(3): 2201-2213.

27. Yusoff, F., Aziz, A., Mohamed, N., and Ab Ghani, S. (2013). Synthesis and characterizations of BSCF at different $\mathrm{pH}$ as future cathode materials for fuel cell. International Journal of Electrochemical Science. 8 (8): 10672-10687.

28. Yusoff, F., Mohamed, N., Azizan, A. and Ab Ghani, S. (2016). The perovskite $\mathrm{Ba}_{0.5} \mathrm{Sr}_{0.5} \mathrm{Co}_{0.2} \mathrm{Fe}_{0.8} \mathrm{O}_{3-} \mathrm{MWCNT}$ modified glassy carbon electrode - its characterization and capacity in oxygen reduction reaction. International Journal of Electrochemical Science, 11(7): 5766-5780.

29. Tukimin, N., Abdullah, J. and Sulaiman, Y. (2017). Development of a PrGo-modified electrode for uric acid determination in the presence of ascorbic acid by an electrochemical technique. Sensors (Switzerland). 17 (7): 1539.

30. Sun, H., Cao, L. and Lu, L. (2011). Magnetite/reduced graphene oxide nanocomposites: one step solvothermal synthesis and use as a novel platform for removal of dye pollutants. Nano Research, 4(6): 550-562.

31. Zhang, W., Chen, J., Li, Y., Yang, W., Zhang, Y. and Zhang, Y. (2017). Novel UIO-66-NO2@XC-72 nanohybrid as an electrode material for simultaneous detection of ascorbic acid, dopamine and uric acid. RSC Advances, 7(10): 5628-5635.

32. Stoyanova, A., Ivanov, S., Tsakova, V. and Bund, A. (2011). Au nanoparticle-polyaniline nanocomposite layers obtained through layer-by-layer adsorption for the simultaneous determination of dopamine and uric acid. Electrochimica Acta, 56(10): 3693-3699.

33. Yusoff, F., Lee, P.S, and Noorashikin, M.S. (2018). The electroxidation of uric acid at zinc oxide/reduced graphene oxide composites modified electrode. AIP Conference Proceeding. 2031:1-6. Kaur, B., Pandiyan, T., Satpati, B. and Srivastava, R. (2013).

34. Simultaneous and sensitive determination of ascorbic acid, dopamine, uric acid, and tryptophan with silver nanoparticles-decorated reduced graphene oxide modified electrode. Colloids and Surfaces B: Biointerfaces, 111: 97-106.

35. Wang, Y. and Tong, L. L. (2010). Electrochemical sensor for simultaneous determination of uric acid, xanthine and hypoxanthine based on poly (bromocresol purple) modified glassy carbon electrode. Sensors and Actuators, B: Chemical, 150(1): 43-49. 
36. Khamlichi, R. El, Bouchta, D., Anouar, E. H., Atia, M. Ben, Attar, A., Choukairi, M., Tazi, S., Ihssane, R., Faiza, C., Khalid, D. and Khalid, R. T. (2017). A novel 1-leucine modified sol-gel-carbon electrode for simultaneous electrochemical detection of homovanillic acid, dopamine and uric acid in neuroblastoma diagnosis. Materials Science and Engineering C, 71: 870-878. 